\title{
La emancipación de América
}

\author{
Jaime E. Rodríguez $O{ }^{*}$
}

\section{Resumen}

Este ensayo compara y contrasta los procesos de independencia de Estados Unidos, Haití y la América española. La América británica, ayudada por España y Francia, logró su independencia como consecuencia de una guerra internacional y por medio de un acuerdo internacional, el Tratado de París de 1783. En Haití, la reacción de los residentes blancos a la revolución francesa provocó una rebelión y una revolución encabezadas por los esclavos; ambas culminaron con éxito y transformaron totalmente a la colonia. La invasión napoleónica de España en 1808 puso en marcha una revolución política que estableció un gobierno representativo liberal en el mundo hispánico, destruido por las luchas de independencia. Ni España ni los países de la América española pudieron recuperarse lo suficiente para desarrollarse como naciones fuertes durante el siglo XIX.
Palabras clave:

Independencia, Constitución de Cádiz, Haití, Estados Unidos, Hispanoamérica, monarquía, autonomía.

\section{Abstract}

The essay compares and contrasts the processes of independence of the United States, Haiti, and Spanish America. British America, aided by Spain and France, achieved its independence as part of an international war and through an international settlement, the Treaty of Paris of 1783. In Haiti the reaction by white residents to the French Revolution sparked a successful slave rebellion and revolution that totally transformed the colony. Napoleon's 1808 invasion of Spain triggered a political revolution that established a liberal representative government in the Spanish world, destroyed by the Spanish American independence. Neither Spain nor the Spanish American countries managed to recover sufficiently to become developed nations in the $19^{\text {th }}$ century.

* Profesor de historia del Departamento de Historia de la Universidad de California, Irvine. Correo electrónico: jerodrig@uci.edu

Una versión anterior de este ensayo fue presentada en el XX Congreso Internacional de la Asociación de Esdudios Latinoamericanos (LASA) que se efectuó en Guadalajara, Jalisco, México del 17 al 19 de abril, 1997. También fue publicado en inglés en The American Historial Review, vol. 105, núm. 1, febrero de 2000, pp. 131-152. Agradezco a Linda A. Rodríguez, William F. Sater , Kathryn Vincent y María del Refugio González, al igual que a Michael Grossberg y a dos lectores anónimos del AHR por sus sugerencias para mejorar este ensayo. Este trabajo se publica en español con el permiso de la American Historical Association. Asimismo, agradezco a los lectores anónimos de Secuencia por sus sugerencias para mejorar la versión española de este artículo. 
No creyendo en Europa que hay otra América que la que la nación posee, se ha formado en cada una nomenclatura errónea... En Francia, generalmente, cuando hablan de América entienden a Santo Domingo; en Portugal a Brasil; en Inglaterra llaman a sus islas como Jamaica en el archipiélago caribe, nuestras Indias o Indias del Oeste, y para los ingleses no hay otra Norteamérica que los Estados Unidos. Toda la América española, es Sud-América, aunque la mayor parte de ella está en el norte. Los Estado Unidos siguen este lenguaje, y se ofenden, cuando nosotros para contradistinguirlos los $11 \mathrm{a}$ mamos angloamericanos. Ellos sólo quieren ser americanos o norteamericanos aunque uno ni otro nombre puede convenirles exclusivamente. Americanos de los Estados Unidos es muy largo, y al cabo tendrán que contentarse con el nombre de guasintones, de su capital Washington...; como ellos nos llaman mexicanos de nuestra capital...

Servando Teresa de Mier Washington, 1820

$\mathrm{L}$ a emancipación de la mayor parte de América -o sea del hemisferio occidental- puede entenderse mejor como una reacción de los colonos contra los actos y los acontecimientos que ocurrieron en sus madres patrias correspondientes. A pesar de las profundas diferencias entre las sociedades hispano, anglo y francoamericanas, cada una comenzó su proceso hacia la independencia en respuesta a las amenazas que la metrópoli infligía a sus propios intereses. Además, este proceso fue también el fruto de un sentimiento imperante: las colonias que- rían ser una parte íntegra e importante de su monarquía. ${ }^{1}$ Los dirigentes de los movimientos independentistas se consideraban a sí mismos británicos, franceses y españoles en defensa de sus derechos como ciudadanos británicos, franceses y españoles. La estructura social y política, la base de recursos a disposición de cada colonia y, sobre todo, la situación temporal y el contexto de que dependía la emancipación en cada región, afectó su proceso independentista y determinó el futuro de las naciones recientemente independientes.

\section{LAS NUEVAS SOCIEDADES}

Las monarquías que conquistaron y fundaron el nuevo mundo durante los siglos XVI y XVII no eran naciones-Estado modernas. ${ }^{2}$ A pesar de que las coronas española, inglesa y francesa obtuvieron primero poder sobre territorios

\footnotetext{
${ }^{1}$ En este ensayo utilicé el término "monarquía" en vez de la palabra "imperio" por varias razones. En primer lugar, la monarquía es una forma de gobierno como también lo es la "república". En segundo, el término imperio implica una condición de subordinación que no existía durante esa época y que los pueblos de esas monarquías, ya en Europa o en América, no aceptaban. Ese tipo de relación subordinada es característica de los imperios europeos que surgen en el siglo XIX. Y finalmente, el término imperio sugiere cierta centralización y control que no existían en ese momento.

${ }^{2}$ La monarquía española identificó a sus partes componentes como reinos, principalidades, condados, ducados, etc. El término "virreinato" se utilizaba en castellano para denominar las áreas administradas por un virrey. La monarquía española poseía virreinatos tanto en Europa como en América. A las regiones de la América española se las llamaba reinos y sus
} 
vecinos en el viejo mundo, la naturaleza de tales conquistas forjó solamente diferentes tipos de relaciones entre los pueblos incluidos así y la sociedad dominante.

Los gobernantes españoles, por ejemplo, incorporaron inicialmente a sus reinos ibéricos, pueblos -los judíos y los musulmanes- que aunque de procedencia caucásica, se percibían como gente que pertenecía a culturas diferentes. Su expansión a África del norte y a las islas Canarias incorporó subsecuentemente a otros grupos a la confederación comprendida por la monarquía española. En su apogeo, la corona española estaba constituida por toda la península ibérica; Sicilia; partes de Italia, Francia, y las Alemanias; Flandes y Holanda; partes del África del norte; algunas islas en el Mediterráneo y cerca de la costa oeste de África; e igualmente partes de América, islas del Pacífico, las Filipinas y partes de la India. ${ }^{3}$ Aunque los monarcas españoles

habitantes no se consideraban a sí mismos "colonos" en el sentido moderno de la palabra -personas que viven en una colonia subordinada. Véanse los ensayos en Greengrass (comp.), Conquest, 1991, y Elliott, "Europe", 1992, pp. 52-69.

${ }^{3}$ Los historiadores anteriores, como Roger B. Merriman, entendieron la monarquía española como una gran confederación; véase su Rise, 1918-1934. En contraste, los estudiosos más recientes suelen concentrarse en las partes individuales de la monarquía. Véase, por ejemplo, el libro de Ernest Belenguer, Imperio, 1994, el cual examina sólo la parte europea de la monarquía española. La mayoría de las síntesis de las posesiones del nuevo mundo ya no se limitan a las de la América española, sino que discuten toda la Amćrica Latina; un buen ejemplo de dicha aproximación se encuentra en la obra de Burkholder, Colonial, 1994. impusieron la unidad religiosa por medio de la fuerza en 1492, no procuraron a la vez ni la unidad lingüística ni la uniformidad cultural. ${ }^{4}$ Como herederos de siglos de dominio musulmán en la península ibérica, los reyes españoles concibieron su monarquía como universal y compuesta por muchas tierras, pueblos y culturas, no todas en igualdad de condiciones. Los indios de América eran considerados un grupo más dentro de la monarquía, pero no obstante, eran un grupo especial.

El nuevo mundo español estaba organizado como dos sistemas legales: la República de Indios para los indígenas, y para todos los demás, la República de Españoles. Los indios llegaron a ser súbditos, aunque en un nivel subordinado, de la corona española, al igual que los judíos y los cristianos lo habían sido bajo el poder musulmán. ${ }^{5}$ La distinción,

\footnotetext{
${ }^{4}$ Pese a que el castellano -la lengua generalmente conocida como el español- se convirtió en la lengua dominante dentro de la monarquía, no fue la única que se hablaba en la península. Más importante aún, los españoles que se interesaron en las lenguas indígenas proveyeron alfabetos y gramáticas a dichas lenguas desde muy temprano. La primera gramática castellana se publicó en 1492, por ejemplo, mientras que la primera gramática náhuatl, apareció en 1531, (comunicación personal con Miguel León Portilla, 6 de octubre, 1997).

${ }^{5}$ Con frecuencia se afirma que a los indigenas se los consideraba menores de edad. Esto no es enteramente correcto. El derecho español, el cual se basaba en el derecho romano, distinguía entre dos formas de minoría legal. La primera, infantes e impúberes $\multimap$ sea, personas de 16 años o menos- carecían de independencia legal y eran supervisados por un tutor. La segunda comprendía individuos menores de 25 años -la edad de mayoría legal- y mayores de 16. Éstos tenían el derecho de actuar indepen-
} 


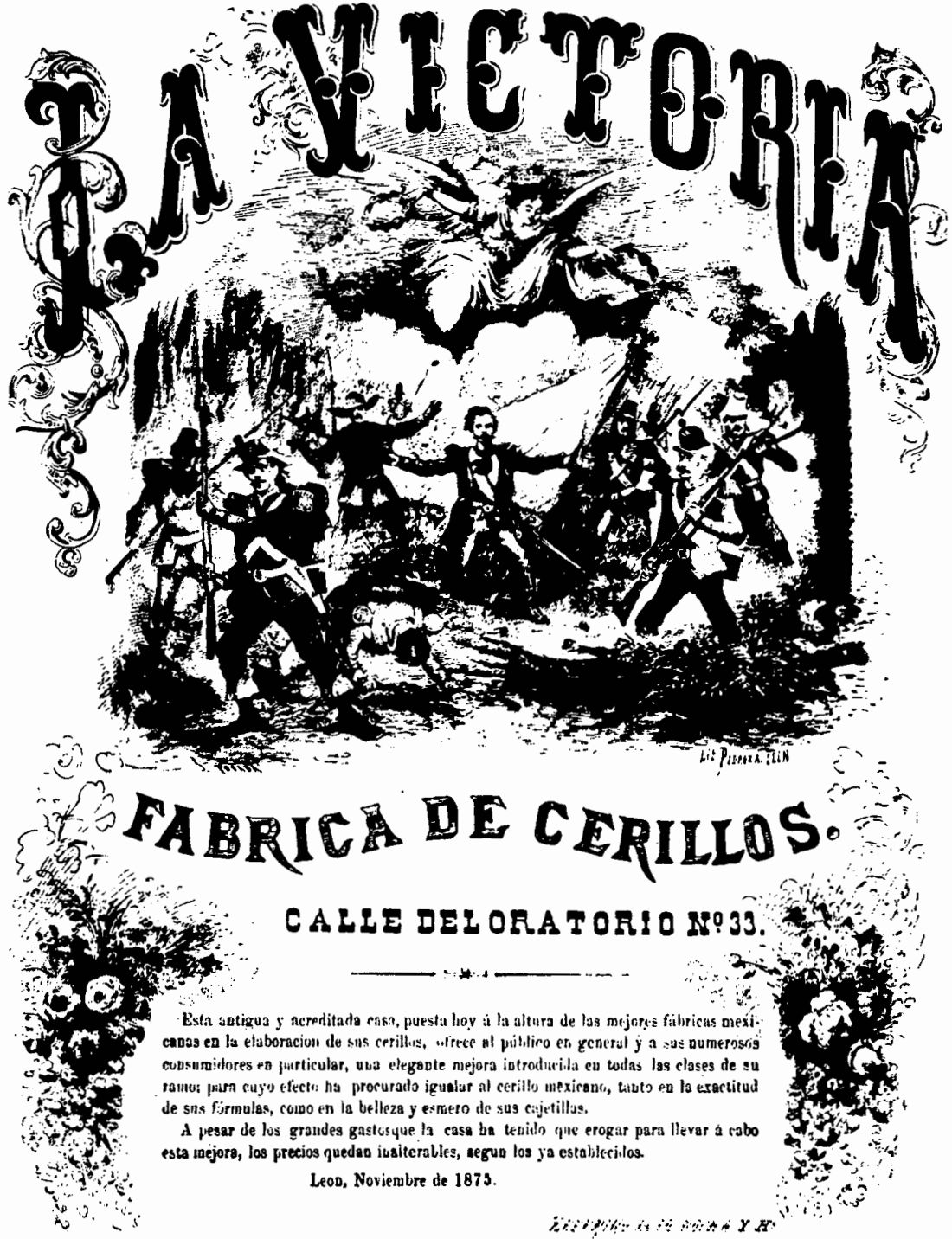


sin embargo, se mostró imposible de mantener, ya que la monarquía española era demasiado vasta y las tierras que ocupaba estaban muy pobladas para que los europeos se convirtieran en el grupo mayoritario en América. Con el paso de los años, el mestizaje y el desarrollo económico transformaron los reinos de Hispanoamérica en sociedades multirraciales en las que los indios, aunque legalmente protegidos y mantenidos en un nivel secundario, ingresaron a la sociedad mayoritaria como mestizos culturales y, muy frecuentemente, como mestizos biológicos. Los africanos y los asiáticos traídos al nuevo mundo fueron sujetos de un proceso similar de integración cultural y biológica. Aunque surgió una jerarquía de castas el desarrollo económico y el crecimiento de la población dieron como resultado, en particular durante la segunda mitad del siglo XVIII, una considerable movilidad racial y social. ${ }^{6}$

La experiencia inglesa tuvo marcadas diferencias, a pesar de la violencia que a veces acompañó a la conquista de Irlanda y a la incorporación de Gales y Escocia, dichos acontecimientos no constituyeron una inclusión de culturas fundamentalmente diferentes. No

dientemente en todos los asuntos legales, pero eran supervisados por un curator que los protegía en caso de que otros "abusaran de su falta de experiencia, falta de malicia, o su incapacidad". A los indios de la América española se los consideraba menores en el segundo sentido. En su caso, el rey -o sea la monarquía- funcionaba como su curator. Véase González, Historia, 1997, p. 36.

6 Rodríguez, Independencia, 1996, pp. 21 . 26. Véase también MacLachlan, Forging, 1990, pp. 196-248. obstante, los ingleses -protestantesconsideraban que los irlandeses, como católicos, eran unos bárbaros salvajes "sólo nominalmente cristianos y generalmente tercos". ${ }^{7}$ Después, percibieron a los indios de Norteamérica de la misma manera: como gente salvaje que no se podía incorporar a la "sociedad civilizada". ${ }^{8}$ Así que los indios que habitaban las regiones conquistadas y colonizadas por la corona inglesa se encontraron a sí mismos como desplazados. Como explica Patricia Seed:

Las metas fundamentales de la colonización inglesa se basaron en la imposición de su autoridad sobre las tierras indigenas, aclarando que Norteamćrica era una "tierra vacante", cuyos ocupantes no utilizaban el fértil suelo agrícola de una manera útil y apropiada. Mientras que la corona española declaró oficialmente a los indios sus súbditos y vasallos en 1542, los indios nunca llegaron a ser colectivamente súbditos cle la corona inglesa (a excepción de casos aislados), y no llegaron a ser ciuchadanos de Estados Unidos sino hasta $1924 .^{9}$

Además, la gran población de esclavos de origen africano, ubicada principalmente en el sur, así como la gente libre de color, permaneció al margen de la sociedad. Para la segunda mitad del siglo XviI, el grupo que dominaba las colonias británicas americanas, aborrecía al mestizaje y excluía a los no blancos -y también a ciertos blancosde participar plenamente en la sociedad. ${ }^{10}$

7 Morgan, American, 1975, p. 20.

" Canny, "Ideology", 1973, pp. 575-598

9Seed, "Are these?", 1993, p. 651.

${ }^{10}$ Horsman, Race, 1981, p. 104. 
Los exploradores, misioneros, mercaderes y colonos franceses se establecieron primero en Norteamérica -en Canadá y Luisiana- durante los siglos XVI y XVII, y después en las islas del Caribe. Francia perdió la guerra de los Siete Años y, consecuentemente, en 1763 tuvo que ceder sus escasamente pobladas posesiones en Norteamérica: Canadá a Gran Bretaña y Luisiana a España. ${ }^{11}$ No obstante, sus valiosísimas islas en el Caribe permanecieron bajo dominio francés. Inicialmente, durante las postrimerías del siglo XVII, engagés -sirvientes por contrato- eran reclutados en Francia para trabajar por un periodo de tres años en las Indias Occidentales. Pero cuando creció la economía de plantación, grandes cantidades de esclavos de origen africano reemplazaron a los engagés por ser una fuerza laboral más económica y fiable. Hacia finales del siglo Xvill, los terratenientes de Saint Domingue importaban 30000 esclavos africanos al año para satisfacer sus necesidades de trabajo.

Los esclavos importados constituían la mayoría en su sociedad y formaban la base de la pirámide social. Sobre ella estaba un grupo libre de gente de color, gens de couleur, compuesto principalmente por mestizos y por unos pocos negros. De esta clase social minoritaria se formó una pequeña elite rica, sofisticada y culta vinculada a Francia. Pero los europeos no constituyeron en Saint Domingue un grupo socialmente homogéneo. Los grand blancs,

${ }^{11}$ Eccles, France, 1990, pp. 1-221; Meyer, Francia, 1992; Seed, Ceremonies, 1995, pp. 4168.

LA EMANCIPACIÓN DE AMÉRICA o sea los hacendados, altos funcionarios y grandes mercaderes, constituían allí la elite política, social y económica. En contraste, los petit blancs, que en su mayoría descendían de los engagés del siglo xvi, se encontraban en una posición ambigua; consideraban que eran racialmente superiores a la elite compuesta por la gens de couleur, pero carecían de la riqueza y la educación de ésta.

Como indica Franklin Knight, la estructura social de la colonia francesa reflejaba "la distorsión estructural" de una "sociedad explotadora de esclavos de plantación". ${ }^{12}$ La gente estaba dividida tanto por raza como por estado socioeconómico: los grands blancs veían a los petit blancs con desprecio; éstos, por otra parte, temían y odiaban a la gente libre de color que frecuentemente ocupaba una posición superior en términos económicos y culturales, y la gens de couleur, aunque desdeñosa de los petits blancs, temía y detestaba a los esclavos. ${ }^{13}$

\section{El pacto social}

Las tres monarquías gobernaron sus posesiones americanas por medio del consentimiento, no por medio de la fuerza. Y las tres se vieron obligadas a conceder a sus colonos más autonomía que a la gente de la metrópoli, tanto por la escasez de recursos de la misma para desarrollar sus regiones, como por la superioridad de oportunidades

\footnotetext{
12 Knight, "Haitian", 2000, p. 108.

${ }^{13} \mathrm{Ott}$, Haitian, 1973, pp. 3-21; Fick, Making, 1990, pp. 15-28.
} 
económicas que el nuevo mundo proveía en relación con el viejo mundo. Como resultado, en gradaciones que varían, las tres coronas ejercieron una forma de gobierno que algunos historiadores han llamado de "negligencia benigna". Durante el siglo xvI y la primera parte del xvin, el poder real fue escasamente sentido por los habitantes de América, los cuales se gobernaban esencialmente a sí mismos. Mas a pesar de las semejanzas que compartían, las tres monarquías mantuvieron su autoridad en el nuevo mundo de manera muy distinta.

La estructura de la monarquía espanola parece que era altamente centralizada. El rey administraba sus posesiones americanas a través del Consejo de Indias, mismo que vigilaba los virreinatos, capitanías generales $\mathbf{y}$ otras subdivisiones administrativas gobernadas por virreyes y otros funcionarios reales. Sin embargo, la corona carecía en verdad de recursos fiscales y coercitivos para reforzar su voluntad. Y a pesar de que las cortes -asambleas representativas- aún no se habían establecido en el nuevo mundo, un gran número de corporaciones representaba los intereses de sus habitantes.

La sociedad indígena, que gozaba del derecho a sus tierras, a su lenguaje, a su cultura, a sus leyes y a sus tradiciones bajo la República de Indios, poseía además sus propios gobiernos, popularmente conocidos como repúblicas. Situados en las áreas de los asentamientos prehispánicos, estos gobiernos regionales se componían de la cabecera, el pueblo principal y la sede de administración, con aldeas subordinadas llamadas pueblos sujetos. Las re- públicas no estaban aisladas. Aun en áreas de alta población indígena, esas entidades políticas coexistían con ciudades españolas, pueblos mestizos y mulatos, y con heredades de varios tipos. De hecho, San Juan Tenochtitlan y Santiago Tlatelolco, las sucesoras de las dos ciudades-islas de que se componía la ciudad de México prehispánica -Tenochtitlan-, coexistieron durante todo el periodo colonial con la capital española, la ciudad de México, en sí la ciudad más grande del hemisferio occidental. ${ }^{14}$

La República de Españoles, que se expandió con el tiempo no sólo a causa del aumento de su población, sino también del mestizaje y la aculturación, poseía un sinnúmero de organismos representativos corporativos. Ayuntamientos, universidades, cabildos eclesiásticos, conventos, cofradías, organizaciones mineras y mercantiles y numerosos gremios de artesanos elegian a los funcionarios que representaban a sus constituyentes. Todas estas entidades corporativas, al igual que las repúblicas, disfrutaban en gran medida de autogobierno y transmitían sus opiniones a autoridades superiores, tales como las audiencias y los virreyes, o directamente al Consejo de Indias y al rey. ${ }^{15}$

Los hispanoamericanos consideraban que sus patrias eran reinos de la

${ }^{14}$ Existe para México la mejor literatura sobre el tema de las républicas. Véase, por ejemplo, Miranda, Ideas, 1978; Lira, Comunidades, 1983; Gibson, Aztecs, 1964, y Haskett, Indigenous, 1991. $38,67.70$

5 Rodríguez, Independencia, 1996, pp. 34- 
monarquía española universal, y no colonias. Estaban convencidos que una constitución no escrita requería que las autoridades reales consultaran a los súbditos del rey en el nuevo mundo. Como ha observado John Phelan, "normalmente surgía un compromiso factible entre lo que idealmente querían las autoridades centrales y lo que las condiciones y las presiones locales tolerarían". ${ }^{16}$

La América británica, al igual que su equivalente español, era en palabras de Jack Greene "un imperio consensual". ${ }^{17}$ Sin embargo, se diferenciaba de la española y la francesa en que su población de colonos blancos era sustancialmente mayor. Esta población de colonos blancos, no los indios, ni la gente libre de color, ni los esclavos, son los privilegiados por los historiadores estadunidenses cuando escriben sobre los derechos y las oportunidades disponibles en las trece colonias. ${ }^{18} \mathrm{Y}$ entonces sucede que, si uno se limita a considerar a ese grupo importante exclusivamente e ignora a los demás, se acepta que los británico-americanos poseían más derechos y libertades que los otros americanos. Pero sólo ellos gozaban de las asambleas locales. (A pesar de que, en teoría, los hispanoamericanos tenían el derecho a convocar sus propias cortes, esto nunca aconteció.) Además, estos británico-americanos blancos probablemente ejercieron un mayor grado

${ }^{16}$ Phelan, People, 1978, p. XVIII.

${ }^{17}$ Greene, "American", 2000, p. 96

${ }^{18}$ Wood, por otro lado, argumenta que la gente libre de color poseía un estatus similar al de los blancos "plebeyos". Véase su obra Radi. calism, 1992, pp. 11-56. de autogobierno que los hispanoamericanos o los habitantes de Saint Domingue.

Las Antillas francesas desarrollaron también una forma de autogobierno a principios del siglo XVII. Limitado a la minoría blanca y dominado por los grands blancs, surgió un sistema de consejos superiores y mostró su capacidad para ignorar las ordenanzas reales que desagradaban a los colonos. De hecho, los consejos superiores aspiraron a tomar el papel del Parlement de París, reclamando el derecho a registrar las leyes reales. A pesar de que la naturaleza de la representación y la negociación era mucho más débil en la América francesa que en la española o en la británica, ofrecía no obstante a su población blanca más representación y negociación de la que disponía el pueblo en Francia. ${ }^{19}$ Por tanto, en ciertos grados la observación de Greene de que "lo legal, lo constitucional se determinaba no por un fiat [mandato absoluto], sino por negociación", ${ }^{20}$ se acepta para las tres Américas.

\section{LAS CONDICIONES MATERIALES}

La vida en el nuevo mundo se determinaba, sustancialmente, por los recursos naturales de cada región. Las trece colonias de la América británica poseían extensas tierras fértiles para la agricultura. Y estaban unidas no sólo por la fácil comunicación que la costa proveía, sino además por un magnífico

${ }^{19}$ Eccles, France, 1990, pp. 158-166; Meyer, Francia, 1992.

${ }^{20}$ Greene, "American", 2000, p. 95. 
sistema de ríos. (La adquisición del territorio de Luisiana en 1803 , que incluía la desembocadura del río Mississippi, facilitó aún más el transporte y contribuyó a la dramática expansión de la joven nación estadunidense.) Debido a la mayor disponibilidad de tierras agrícolas, y al bajo costo y a la eficiencia del transporte acuático, la mayoría de los británicos americanos adquirieron una propiedad que los hizo capaces de exportar gran variedad de productos agrícolas a Europa y a las Antillas. Estas condiciones ayudaron a crear las dinámicas clases propietarias que constituyeron las

órdenes sociales igualitarias de los segmentos libres de estas sociedades de colonos, las cuales proveerían un fuerte fundamento a los limitados impulsos igualitarios de la revolución y a la temprana América [británica] republicana

descrita por Greene. ${ }^{21}$ Para finales del siglo Xvw, aproximadamente 5500000 personas, sin incluir a los indios, vivían en la antigua América británica, Estados Unidos.

Hispanoamérica, a pesar de que reclamó la vasta mayoría del continente, poseía una cantidad muy limitada de tierras agrícolas. La tierra más fértil estaba localizada en la escasamente poblada periferia del extremo sur y del extremo norte. Sólo $15 \%$ del México actual es arable sin irrigación, mientras que las vastas y fértiles Pampas de la Argentina de hoy en día-como las grandes praderas de Norteamérica- se consideraban desiertos en ese enton-

\footnotetext{
${ }^{21}$ Ibid., p. 97.
}

ces, debido a que no se podían cultivar con la tecnología de la época. Las porciones pobladas de la América española del siglo Xvil, el corazón de la región, se caracterizaban por estar compuestas de masivas cordilleras, barrancos escarpados, grandes desiertos y vastas selvas fluviales, barreras todas formidables para la comunicación. A pesar de las extensas costas de Hispanoamérica en ambos lados del continente, la embarcación costera estaba restringida por la falta de buenos puertos y porque la mayoría de la población y de los centros de producción se hallaban ubicados en las tierras montañosas, lejos de la costa. Además, como ninguna de las áreas pobladas tenía ríos navegables, el costo y la dificultad del transporte terrestre, universalmente más caro que el acuático, limitaba el comercio externo a uno que otro producto tropical agrícola y a exportaciones costosas, tales como la plata. Como resultado, los reinos hispanoamericanos, aunque eran parte de la misma monarquía, tenían poco contacto entre sí, a menos que fueran vecinos.

El ambiente físico no solamente determinó la naturaleza de la economía, sino también la de la sociedad. Nueva España, dotada con vastos depósitos de plata, desarrolló una economía compleja y opulenta. La grande y avanzada población indígena se adaptó rápidamente al nuevo sistema político y social, y aprendió a proteger sus propios intereses tanto dentro de la República de Indios como de la República de Españoles. El virreinato se convirtió gradualmente en una sociedad multirracial, cuyos miembros se integraron cultural y económicamente, en varios 


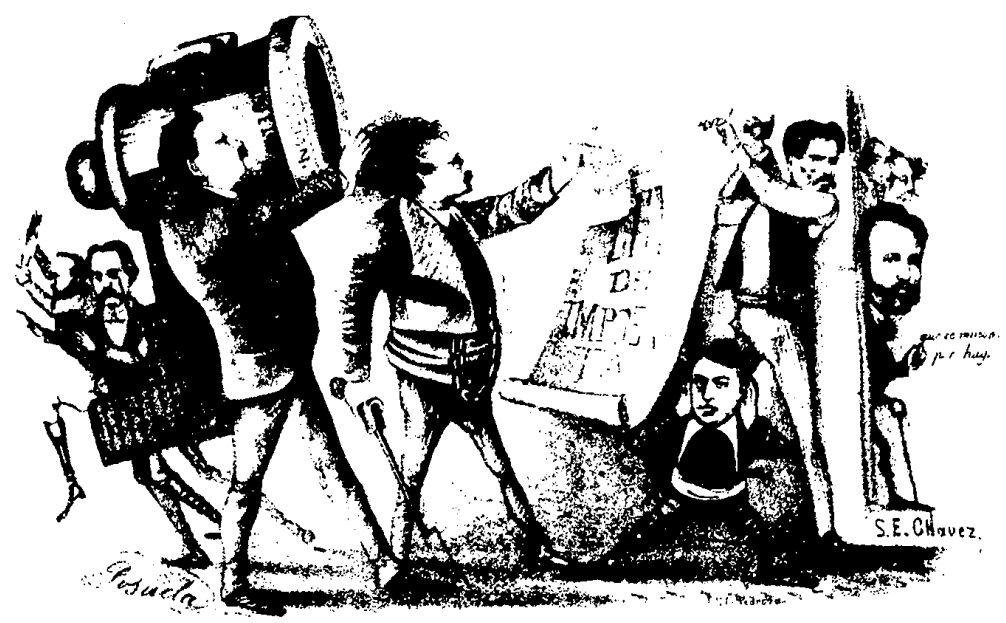

niveles, conformando una sociedad mestiza que no era ya ni india ni espanola. ${ }^{22}$ A finales del siglo XVIII, Nueva España, que contaba con una población de casi 6000000 de habitantes, era la parte más rica, más poblada y más de. sarrollada de la monarquía española en América. En contraste, la de Río de la Plata, una región periférica escasamente poblada y lejos de Europa, no fue elevada a la condición de virreinato sino hasta 1776 . Anteriormente, el interior había orientado su producción agrícola y ganadera a las minas de plata en el Alto Perú, mientras que Buenos Aires y las Pampas criaban su propio ganado. El área no tuvo una expansión rápida sino hasta 1776 , cuando Buenos Aires se convirtió en la salida del comercio del interior, que provenía particularmente de las minas de plata

22 MacLachlan, Forging, 1990, pp. 144-228. de Charcas, hoy Bolivia. Para 1800, la región, excluido el Alto Perú, poseía una población de aproximadamente 500000 habitantes, los cuales se componían de una pequeña clase blanca, la elite de la región, un grupo de mestizos que constituían el medio de la pirámide, y una población grande de indígenas nómadas.

Saint Domingue, aunque sólo ocupaba una tercera parte del oeste de la isla de La Española, se convirtió durante la segunda mitad del siglo Xvill en la colonia más productiva de las Indias Occidentales. Como observa David Geggus, en las décadas de 1780-1790 Saint Domingue contaba con

alrededor de $40 \%$ de la exportación de Francia [...] En las planicies costeras de esta pequeña colonia, un poco más grande que Gales, se cultivaban aproximadamente las dos quintas partes de la caña de azúcar del mundo, mientras 
que de su montañoso interior procedía más de la mitad del café en el mundo. ${ }^{23}$

Su productividad condenó a la mayoría de los habitantes de Saint Domingue a la explotación. Como indica Knight:

Una población de cerca de 25000 transeúntes psicológicos dominaba la pirámide social, la cual incluía un estrato intermedio subordinado de, aproximadamente, el mismo número de personas libres de raza mixta[...], y un grupo mayoritario oprimido, denigrado, servil y explotado de aproximadamente 500000 trabajadores de África o de ascendencia africana. ${ }^{24}$

\section{LAS REFORMAS IMPERIALES}

Dos tendencias conflictivas surgieron en el mundo atlántico durante la segunda mitad del siglo xvir: la aserción de los americanos -tanto españoles como británicos- de una consciencia de sí y el intento de las monarquías hanoverianas y borbónicas de obtener un control más firme de sus Américas en pro de transformarlas en colonias provechosas. Desde la zona de Río de la Plata en el sur hasta Nueva Inglaterra en el norte, los pueblos de las sociedades de colonos se identificaban con sus patrias, sus localidades, a las cuales concebían como América. De hecho, fue entonces cuando el nombre de América se hizo prominente; anteriormente, el continente se había

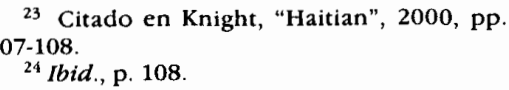

conocido como las Indias. Mientras que los miembros educados de ambas comunidades resaltaban sólo las características particulares de sus tierras y de sus gente, los americanos españoles incorporaron a esto su herencia indígena para interpretar la americanidad; un contraste con los británico-americanos que excluyeron la presencia y la cultura indígena de la suya. Esta distinción se ejemplifica en dos grandes obras de la época: La bistoria antigua de México, de Francisco Javier Clavijero, y Notas sobre Virginia, de Thomas Jefferson. ${ }^{25}$ La primera glorificaba a los antiguos mexicanos, mientras que la segunda exaltaba a los británico-americanos blancos.

Los americanos se consideraban a sí mismos verdaderos españoles o británicos, poseedores de todos los derechos y privilegios de estos pueblos. Los hispanoamericanos desarrollaron una teoría de gobierno que se basaba en un pacto entre el pueblo y el rey, derivando sus derechos de dos fuentes: sus progenitores indios, los dueños originales de la tierra, y sus antepasados españoles, quienes al conquistar el nuevo mundo obtuvieron privilegios de la corona; entre ellos, el derecho de convocar sus propias cortes. No obstante, este pacto no fue hecho entre América y España, sino sólo entre cada reino del nuevo mundo y el monarca. ${ }^{26}$ De igual manera, los británico. 33.

${ }^{25}$ Rodríguez, Independencia, 1996, pp. 26 -

${ }^{26}$ Ibid., pp. 66-70. El padre Servando Teresa de Mier, uno de los abogados más distinguidos de la tesis de los derechos americanos declaró: "Lejos de haber pensado nuestros reyes en dejar nuestras Américas en el sistema colo- 
americanos basaron sus pretensiones de autogobierno en sus derechos como ingleses. En particular, "insistiendo en que cada una de sus legislaturas locales gozara de plena autoridad legislativa y de poder exclusivo para cobrar impuestos dentro de su respectiva jurisdicción". ${ }^{27}$

Aunque tanto la corona española como la británica habían considerado en las décadas de 1740 y 1750 asegurar más el control sobre sus posesiones americanas, muy poco se logró antes de las vísperas de la guerra de los Siete Años. El conflicto, una guerra mundial que se peleó en Europa, América -tanto en el norte como en el sur- y Asia, cambió el balance de poder en el nuevo mundo. Francia se retrajo del continente en 1763, dejando así a España y a Inglaterra como los principales contendientes en el control de América. Las dos monarquías establecieron sustanciosas fuerzas armadas en el nuevo mundo por primera vez, y las dos introdujeron nuevas regulaciones y estructuras diseñadas para lograr un dominio mayor sobre sus vastas y distantes posesiones. Impresionadas por la inmensa riqueza que Francia extraía de sus islas en el Caribe, particularmente de Saint Domingue, Inglaterra y España intentaron transformar sus Américas

nial moderno de otras naciones, no sólo igualaron las nuestras con España, sino con lo mejor de ellas. Es evidente en conclusión: que por la Constitución dada por los reyes de España a las Américas, son reinos independientes de ella sin tener otro vínculo que el rey $[\ldots]$ el cual, según enseñan los publicistas, debe gobernarnos como si sólo fuese rey de ellos." Mier, "Idea", 1988 , p. 57.

27 Greene, Understanding, 1995, pp. 74-75. en colonias en el sentido moderno de la palabra: no sólo ejerciendo ese mayor control, sino buscando obtener ganancias de ellas. Estos cambios fueron conocidos en el mundo español como las reformas borbónicas, y las comparables transformaciones en el mundo británico pueden definirse mejor como las reformas hanoverianas.

\section{LA REVOLUCIÓN AMERICANA}

Como era de esperarse, los americanos, tanto británicos como españoles, se opusieron a este nuevo imperialismo. Las razones por las que se opusieron con tanta fuerza a las nuevas medidas, como la inserción de un ejército permanente, la ley del papel sellado, las leyes de navegación, el impuesto al té, etc., y la razón por la que el gobierno británico insistió en imponer su autoridad siguen aún, en mi opinión, sin entenderse por completo. ${ }^{28}$ Obviamente, los británicos temían que si las exigencias de los colonos se satisfacían, éstos insistirían en la independencia. A la vez, los británicos americanos estaban convencidos de que con las reformas hanoverianas se procuraba privarlos de sus derechos y libertades como ingleses. Claramente, la revolución surgió de "la incapacidad de los oponentes para llegar a un acuerdo sobre la naturaleza del imperio británico". ${ }^{29}$ Además, los británicos, al igual que los españoles más tarde, no se mostraron dispues-

28 Una explicación se ofrece en la obra de Maier, Resistance, 1991. Draper provee una observación algo diferente en Struggle, 1996.

${ }^{29}$ Greene, Understanding, 1995, p. 72. 
tos a aceptar un acuerdo comparable al de la futura Commonwealth (comunidad) británica.

La naturaleza y el proceso de las luchas por la emancipación fueron tan distintos como las tres Américas. La guerra por la independencia de Estados Unidos se convirtió en un conflicto internacional, en el cual Francia y España combatieron contra la Gran Bretaña, tanto por tierra como por mar. En la cúspide del conflicto, Francia instaló una fuerza de más de 10000 hombres en Norteamérica -un ejército superior al ejército real en Nueva España-, mientras las tropas españolas hostigaban a las británicas a lo largo de sus fronteras con Nueva España y una combinación de las fuerzas navales de España y Francia neutralizaban a las embarcaciones británicas en el mar. Como resultado de esta intervención foránea, Estados Unidos obtuvo su independencia por medio de un acuerdo internacional, el Tratado de París de $1783 .^{30}$

Muchos de los fundadores de la nueva nación eran miembros de la oligarquía y, durante la lucha por la independencia, las clases alta y media de la América británica compartían metas moderadas. Otros grupos sociales participaron en la lucha, pero nunca desafiaron a las elites. Así pues, ninguna revolución social amenazaba los intereses de las clases dominantes. ${ }^{31}$ La guerra de

${ }^{30} \mathrm{La}$ lucha por la independencia de Estados Unidos se discute en Middlekauff, Glorious, 1982; Higgenbotham, War, 1971; Smelser, Winning, 1972, y en Wallace, Appeal, 1951.

${ }^{31}$ Por otro lado, Wood, erróneamente en mi opinión, sostiene que la revolución americana fue "tan radical y social como cualquier revolucion en la historia". Radicalism, 1992, p. 5.
Independencia de Estados Unidos se caracterizó por librarse en combates militares tradicionales. Los insurgentes locales con metas fundamentalmente diferentes a las de la elite, son notables por su ausencia. No aconteció ninguna insurrección rural. Los esclavos negros no se rebelaron contra sus amos ni los indios aprovecharon la oportunidad para recuperar las tierras de que habían sido despojados. ${ }^{32}$

En consecuencia, no obstante que existían tensiones regionales y que la primera Constitución estadunidense, los artículos de la confederación, fue descartada rápidamente a favor de la Constitución de 1787 que era más evo. lucionada, la elite británico-americana logró dirigir la nueva nación sin amenazas sustanciales por parte de los otros grupos sociales. ${ }^{33}$ Como ha indicado Greene:

pese a los pronunciamentos universales de la Declaración de Independencia y de la aparente inclusión expresada en la frase "We the People" [Nos, el pucblo] de la Constitución, la revolución americana fue una revolución limitada que realmente sólo se aplicó de inmediato, en su totalidad, a los hombres blancos independientes y de edad adulta. Debido a que una gran proporción de la población americana caía dentro de esta categoría, la revolución americana dio a sus contemporáneos la impresión de ser mucho más justa e incluyen-

${ }^{32}$ Algunos grupos indígenas apoyaron al gobierno británico, pero no surgió ningún movimiento a escala mayor que hubiera amenazado a los británicoamericanos.

${ }^{33}$ Véase Jensen, Articles, 1959; Brown, Redeeming, 1993, y Bruchey, Roots, 1965. 
te de lo que en verdad era. Sin embargo, agrupaciones de personas -esclavos, sirvientes, trabajadores sin propiedad, mujeres, menores de edad, gente libre de ascendencia africana o amerindia, y aun en algunos lugares, los no protestantes- fueron sistemáticamente excluidos del sufragio y del espacio público que garantizaba el sufragio. ${ }^{34}$

Estados Unidos, por tanto, surgió como una república oligárquica que incorporó lentamente a los otros grupos a su plena participación, proceso que aún continúa hoy en día.

\section{LA REVOLUCIÓN HAITIANA}

Los orígenes de la revolución en Saint Domingue, como observa Knight, "provienen de los cambios más amplios ocurridos en el mundo atlántico durante el siglo Xvill". ${ }^{35}$ La revolución americana, por ejemplo, afectó directamente a Francia. El costo de la ayuda a los rebeldes británico-americanos contribuyó a la crisis fiscal y constitucional que destruyó a la monarquía francesa. Cuando la nobleza se negó a aceptar impuestos más elevados, la monarquía fue obligada a convocar a los Estados generales, y cuando ese parlamento se reunió, una coalición entre el tercer Estado y una minoría importante de nobles liberales transformó esa entidad en una Asamblea Nacional en 1789, iniciando así la revolución francesa.

La revolución francesa influyó en la naturaleza y en el proceso de la revolución haitiana. Como apunta Knight:

${ }^{34}$ Greene, Understanding, 1995, p. 389.

${ }^{35}$ Knight, "Haitian", 2000, p. 106.
Los grands blancs percibieron los Derechos del Hombre como derechos y privilegios del hombre burgués, de manera similar a los creadores de la independencia norteamericana en Filadelfia, en 1776. Además, interpretaban la libertad no como un asunto privado, sino como una autonomía colonial más poderosa [...] [En este aspecto, continuaban con la antigua tradición política de sus consejos superiores.] Anhelaban también que la metrópoli les permitiera realizar un comercio más libre para debilitar así los efectos restrictivos del commerce exclusif mercantilista con la madre patria. Los petits blancs querían la igualdad, o sea, la ciudadanía activa para todas las personas blancas, no sólo para los grandes y ricos propietarios, y menos control burocrático de Francia sobre las colonias. Sin embargo, insistían en una fraternidad basada en la blancura de la piel, la cual relacionaban directamente con ser franceses auténticos. Las gens de couleur querían tam. bién la igualdad y la fraternidad, pero basaban su petición en una igualdad de seres libres sin que importira el color de la piel, ya que cumplían con todos los requisitos para ejercer la ciudadanía activa. Los esclavos no formaron parte de la discusión ni de las demandas iniciales, no obstante sus acciones subsecuentes apoyaron claramente la libertad. Sin embargo, no era la libertad de los blancos: la suya era una libertad personal que socavaba su relación con sus amos y con la plantación, y que amenazaba la riqueza de un número considerable de los individuos que ya eran libres. ${ }^{36}$

La violencia en Saint Domingue fue iniciada por los blancos en 1790 . Al lu-

${ }^{36}$ Ibid., p. 110. 
char por el control de la colonia, los grands blancs y los petits blancs no sólo se armaron, sino que también armaron a sus esclavos. Cuando la Asamblea Nacional francesa otorgó derechos políticos a la gente libre de color, los blancos haitianos se unieron temporalmente para limitar el poder político sólo a su raza. En respuesta, la gente libre de color armó a sus esclavos para defender sus intereses. Después de dos años de luchar-blancos y no blancos- por la libertad y la igualdad de la gente libre de Haití; los esclavos comenzaron a luchar por su propia libertad. Pero, aunque Pierre-Dominique Toussaint Louverture obtuvo la victoria temporal para los esclavos en 1793, victoria que la Asamblea Nacional de Francia aparentó ratificar cuando abolió la esclavitud, la lucha continuó por otra década. Los británicos y los españoles, al igual que los franceses, intervinieron en el conflicto, mas las fuerzas de Toussaint Louverture los echaron de la isla, controlaron el disentimiento interno, e inclusive capturaron el Santo Domingo español.

Toussaint Louverture se proclamó a sí mismo gobernador general vitalicio en julio de 1801 , sin declarar la independencia; no obstante, los intentos franceses de volver a imponer el control sobre Saint Domingue causaron la ruptura final. El nuevo emperador de los franceses, Napoleón Bonaparte, quien deseaba restablecer el poder francés en América, despojó a los españoles de Luisiana y, en 1802, despachó un ejército francés a Saint Domingue a restaurar el orden. A pesar de que Toussaint Louverture fue capturado y enviado a prisión a Francia, donde mu- rió, su causa sobrevivió. Jean-Jacques Dessalines, su sucesor, derrotó a los franceses y declaró la independencia de Haití el primero de enero de $1804{ }^{37}$ Como observa Knight:

[Haití] fue un caso único en la historia de las Américas: una revolución completa que produjo una metamorfosis total en la vida social, política, intelectual y económica de la colonia. Socialmente, el estrato más bajo de la sociedad-los esclavos- se convirtieron en ciudadanos libres e independientes. Políticamente, los nuevos ciudadanos crearon el segundo Estado independiente en las Américas, y el primer Estado no europeo que se independizó de los imperios universales europeos. El modelo haitiano de formación de Estado fomentó el pavor xenofóbico en el corazón de todos los blancos, desde Boston hasta Buenos Aires $[\ldots]^{38}$

\section{LA INDEPENDENCIA DE LA AMÉRICA ESPAÑOLA}

Los levantamientos en el mundo espanol difirieron significativamente de los de la América británica y francesa. La independencia de la América española no constituyó sólo un movimiento anticolonial como muchos aseguran, sino que formó parte de la revolución que se operó dentro del mundo hispánico

${ }^{37} \mathrm{La}$ revolución haitiana se discute ampliamente en el estudio clásico de James, Black, 1980; Ott, Haitian, 1973, y Fick, Making, 1990. Dos estudios más recientes colocan el movimiento dentro de su contexto internacional: Hernández Guerrero, Revolución, 1997, y Grafensteìn Gareis, Nueva España, 1997.

${ }^{38}$ Knight, "Haitian,", 2000, pp. 104-105. 
a la vez que ocurrió la disolución de la monarquía española. De hecho, Espana fue una de las nuevas naciones que surgieron a causa de la ruptura de esa entidad monárquica mundial. ${ }^{39}$

España, al igual que Gran Bretaña, intentó reorganizar sus posesiones en el nuevo mundo durante los últimos años del siglo XVIII. Para ello estableció un ejército permanente y una cuantiosa fuerza de milicias provinciales, reorganizó las fronteras administrativas, introdujo un nuevo sistema de administración -las intendencias-, restringió los privilegios del clero, reestructuró el comercio y limitó los puestos de los americanos a los del gobierno de sus patrias.

A pesar de que los hispanoamericanos se opusieron a las reformas borbónicas, en ocasiones violentamente, no imitaron a sus hermanos del norte en la búsqueda de su separación de la corona española. La monarquía española estaba tan segura de la lealtad de sus súbditos americanos, que combatió con ellos contra la Gran Bretaña durante la guerra británico-americana y firmó el Tratado de París de 1783, por el que se concedió la independencia a Estados Unidos.

Sin embargo, las reformas borbónicas hallaron una oposición masiva en toda la América española, y los afectados por los cambios comenzaron a utilizar todo recurso legal para frenar o modificar el nuevo sistema; en ocasiones hasta acudieron a la resistencia armada. El aumento de los impuestos,

\footnotetext{
${ }^{39}$ Este argumento se desarrolla en mi libro, Rodríguez, Independencia, 1996.
}

la expulsión de los jesuitas y otras medidas llevaron a protestas y levantamientos violentos en Quito en 1765, en el centro de Nueva España el siguiente año, y en el Alto Perú de 1777 a 1780. Los alzamientos más serios -el de Túpac Amaru, que amenazó con abarcar todo el virreinato de Perú, entre 1780 y 1783, y el de los Comuneros en Nueva Granada, en 1781- fueron superados con gran dificultad. No obstante, por medio de concesiones y el uso de la fuerza, la corona española logró contener estos levantamientos.

Los hispanoamericanos se opusieron a esas innovaciones que afectaban sus intereses y lograron modificar la mayoría a su gusto y medida. Las reformas de los Borbones eran dañinas inicialmente para algunas regiones o grupos, pero beneficiaban a otros, así que las estructuras políticas y administrativas existentes serían todavía capaces de negociar modificaciones aceptables y de establecer un nuevo equilibrio. No obstante, aunque la crisis constitucional de la monarquía española no llegaba aún al punto de ruptura, los acontecimientos en Europa impidieron un reajuste ordenado. Además, el inicio de la revolución francesa desató 20 años de guerras en las que España se convirtió contra su voluntad en partícipe, lo cual exacerbó la inestabilidad reinante, así que a finales del siglo XVII la monarquía española enfrentaría la peor crisis de su historia. ${ }^{40}$

La revolución política del mundo español comenzó, como observa Virginia Guedea, "con la crisis imperial

\footnotetext{
${ }^{40}$ Ibid., pp. 34-54.
} 
de $1808 " .{ }^{41}$ El colapso de la monarquía española, como resultado de la invasión francesa de la península, y la abdicación de sus gobernantes, inició una serie de eventos que culminaron con el establecimiento de un gobierno representativo en todo el mundo español. El primer paso en este proceso fue la formación de juntas de gobierno locales en España y en América, las cuales invocaron el principio legal de que, en ausencia del rey, la soberanía recaía en el pueblo. En tanto que las provincias peninsulares realizaron fácilmente esa transición, los reinos americanos tuvieron que enfrentar la oposición de los funcionarios reales, de los europeos residentes en América y de sus aliados en el nuevo mundo.

Lo acontecido en España tuvo efectos muy profundos en el nuevo mundo. Opuesto a la dominación francesa, el pueblo español, como indica Guedea, luchó contra su invasor ${ }^{42}$ A pesar de pelear inicialmente divididas, las provincias de la península unieron finalmente sus fuerzas, el 25 de septiembre de 1808 , para formar un gobierno de defensa nacional -la Junta Suprema Central Gubernativa del Reino- y para emprender una guerra de liberación. Sin embargo, el gobierno nacional español no podía derrotar a los franceses sin contar con la ayuda de sus súbditos ultramarinos. En consecuencia, el nuevo gobierno reconoció la igualdad de los reinos americanos y, en 1809 , los invitó a elegir representantes a la Junta Central.

\footnotetext{
${ }^{41}$ Guedea, "Process", 2000, p. 116.

${ }^{42}$ Ibid., p. 116.
}

Aunque restringidas a una elite pequeña, las elecciones aumentaron el poder político de los ayuntamientos, y fueron las primeras de una serie que dieron a los hispanoamericanos la oportunidad de participar en el gobierno en varios niveles. Cuando la Junta Central convocó una asamblea nacional -las Cortes- en 1810, invitó nuevamente a los reinos americanos a enviar a sus delegados ${ }^{43}$ En las elecciones a las Cortes se amplió la participación en comparación con las correspondientes a la Junta Central, incluyendo a "españoles nacidos en América o Asia [...], los domiciliados y residentes en esas tierras, al igual que a los indios y a los hijos de españoles y de indios". ${ }^{44}$ Pero antes de que las Cortes se reunieran, la Junta Central se autodisolvió, y asignó un Consejo de Regencia para que funcionara como poder ejecutivo.

Los diputados de España y América que decretaron en la ciudad de Cádiz la Constitución monárquica española de marzo de 1812, transformaron al mundo hispánico. La Constitución de Cádiz no era solamente un documento español; era tanto una carta americana como española, ya que los diputados americanos a las Cortes desempeñaron un papel central en su elaboración. La carta de 1812 abolió las instituciones señoriales, la Inquisición, el tributo in. dígena, el trabajo forzoso -tanto en América como en la península- y aseguró el control del Estado sobre la Iglesia. Creó un Estado unitario con leyes iguales para todas las partes do.

\footnotetext{
${ }^{43}$ Guedea, "Primeras", 1991, pp. 1-7.

${ }^{44}$ Citado en Rodríguez, Independencia, 1996, p. 107
} 


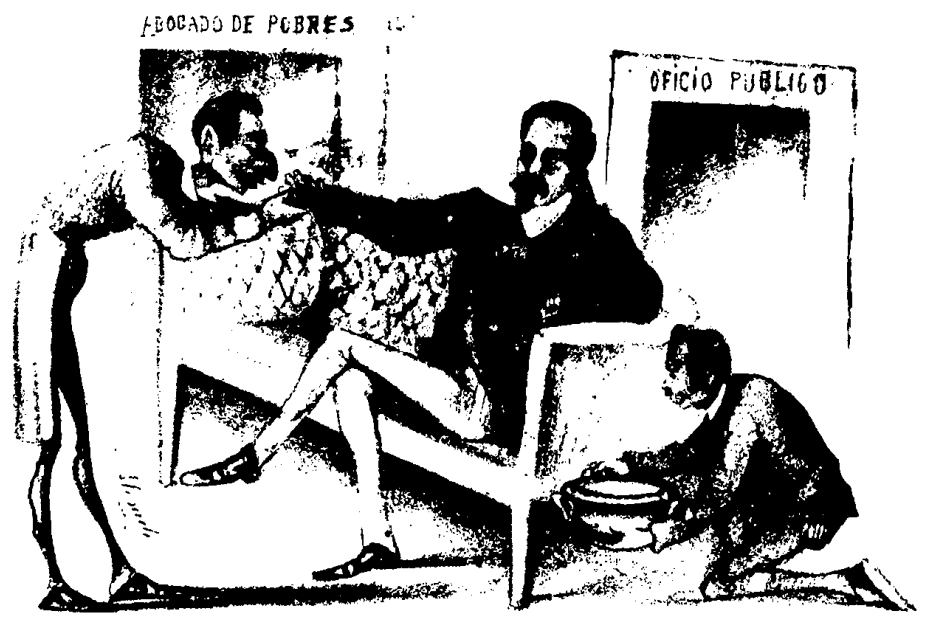

minadas por la monarquía española, restringió sustancialmente la autoridad del rey y dotó a las Cortes de poder de decisión. Cuando concedió la ciudadanía a todos los hombres adultos, con excepción de los de ascendencia africana, sin requerirles saber leer ni cumplir con los requisitos de propiedad, la Constitución de Cádiz superó las leyes de todos los gobiernos representativos existentes, tales como los de Gran Bretaña, Estados Unidos y Francia, para dotar de derechos políticos a la gran mayoría de la población masculina. ${ }^{45}$

${ }^{45}$ Es indudable que el racismo contribuyó sustancialmente a la negación de los derechos políticos a las castas, la gente de ascendencia africana. La cuestión, no obstante, fue también afectada por los cálculos equivocados de las poblaciones de España y América. En ese momento, España tenía una población de aproximadamente 10500000 habitantes, mien-
La Constitución de la monarquía española no sólo expandió el electorado, sino que aumentó además extraordinariamente la esfera de la actividad política. La nueva Carta constitucional estableció tres niveles de gobierno repre. sentativo: la ciudad (el Ayuntamiento constitucional), la provincia (la Diputación Provincial) y el gobierno monárquico (las Cortes). Al permitir que las ciudades y los pueblos con mil o más habitantes formaran ayuntamientos,

tras que según las elevadas cifras de Alexander von Humbolt aceptadas como correctas en el debate, la América española tenía una población de cerca de 16000 000. Debido a que se creía que las castas constituían un número de aproximadamente 6000000 , su exclusión reducía la cifra de la población contada para propósitos de representación. Por tanto, los peninsulares aseguraron que no se convertirían en una minoría en su propio Parlamento. Rodríguez, Independencia, 1996, pp. 132-149. 
transfirió el poder político a las localidades mismas que incorporaron gran cantidad de personas al proceso político. Los estudios sobre las elecciones populares en Hispanoamérica demuestran que, pese a que la elite dominaba la política, cientos de miles de hom. bres de la clase media -y baja- incluyendo indios, mestizos y castas, participaron en ella. ${ }^{46}$

Sin embargo, no obstante esta democratización sin paralelo del sistema político, la guerra civil estalló en Hispanoamérica debido a que ciertos grupos se negaron a aceptar ser gobernados por España insistiendo en la formación de juntas locales, mientras otros se opusieron porque reconocían a las nuevas autoridades en la península. Estos americanos invocaron el mismo principio jurídico que sus equivalentes peninsulares: en ausencia del rey, la soberanía recae en el pueblo. Los que apoyaban la autonomía fundaron sus argumentos en la Constitución americana no escrita -el pacto individual entre los reinos y el monarca. Conforme a su interpretación, si se llegara a dañar esa relación, por cualquier motivo, nada ataba a un reino americano a España ni a cualquier otra parte del nuevo mundo. Pese a esto, algunos españoles e hispanoamericanos del nuevo mundo que afirmaban la legitimidad del Consejo de Regencia y de las Cortes se opusieron a la formación de juntas locales; algunas provincias dentro de los reinos

${ }^{46}$ Véase Guedea, "Primeras", 1991, pp. 1-28; su "Pueblo", 1994, pp. 27-61, y su Busca, 1992, pp. 233-315. Véase además Rodríguez, Independencia, 1996, pp. 120-127, y también "Primeras", 1999. americanos llegaron a la conclusión de que ellas también tenían derecho a formar sus propios gobiernos locales, punto de vista que las ciudades capitales rechazaron con fuerza. En algunas regiones, las propias elites estaban divididas y, en algunos casos, el conflicto surgió entre las ciudades y el campo.

Así, surgieron las guerras civiles en el nuevo mundo, luchas que echaron a los patrocinadores del gobierno nacional español contra las juntas americanas, a las capitales contra las provincias, a las elites contra sí mismas y a las ciudades contra el campo. Las condiciones locales determinaron la naturaleza y la manera en que los conflictos se desarrollaron. Como indica Guedea, debido al conflicto entre los europeros y Napoleón en 1808, comenzó el movimiento autonomista en Nueva España, movimiento que se inició con conspiraciones urbanas subsecuentemente acompañadas de insurgencias rurales que se dispersaron por todas partes. Con la excepción del Perú, los reinos de Sudamérica establecieron juntas de gobierno en 1809 y en 1810 , mismas que asumieron la autoridad en nombre del rey encarcelado, Carlos IV, y que procuraron dominar sus regiones.

Debido a que todas las áreas de la monarquía española compartían la misma cultura política, todos los movimientos, incluyendo a las insurgencias de Nueva España, justificaron sus acciones bajo los mismos fundamentos y con base en términos casi idénticos. Determinaron que, por causa del encarcelamiento del rey, la soberanía recaía en ellos. En un principio, la mayoría de las juntas hispanoamericanas se componían tanto de peninsulares 
como de americanos. Cuando el colapso de España bajo el poder francés parecía inevitable, los americanos más radicales tomaron el control echando a los europeos del gobierno. Aunque la mayoría de las juntas de gobierno actuaron como si fuesen independientes y aunque algunas eventualmente declararon su independencia de la monarquía española, la mayor parte de la población políticamente activa de la América española deseaba mantener lazos con la corona, y se mostró opuesta a separarse totalmente de ella.

Los movimientos hispanoamericanos de 1810, al igual que los de España en 1808, surgieron del deseo del pueblo de mantenerse independiente del dominio francés. La gran diferencia entre la península y América fue que las regiones de España lucharon contra un enemigo externo, en tanto que los reinos del nuevo mundo afrontaron divisiones internas. Así el conflicto en la América española creció y menguó durante el primer periodo constitucional (1810-1814).

En ocasiones, cuando las autoridades actuaban en forma moderada, parecía posible establecer un acuerdo con la península. Y cuando fue libera. do Fernando VII y regresó al trono en 1814 , se dio la mejor oportunidad para restablecer la unidad del mundo hispánico. Casi todos los sucesos que habían ocurrido desde 1808 -la lucha contra los franceses, la revolución política llevada a cabo por las Cortes y los movimientos de autonomía en América- habían sido realizados en su nombre. No obstante que el rey había abolido la Constitución, parecía al principio que aceptaría las reformas moderadas, pero al final optó por recurrir a la fuerza para restablecer el orden real en América. Libres de las restricciones constitucionales, las autoridades reales aplastaron en el nuevo mundo a la mayoría de los movimientos autonomistas, tales como los de Nueva España, Venezuela, Nueva Granada, Quito y Chile. Sólo el aislado Río de la Plata permaneció inmune al débil poder de la monarquía española.

La represión por parte de la corona inclinó a la minoría de la población políticamente activa de Hispanoamérica que favorecía la independencia, a que actuara decisivamente. En América del Sur, generales autonombrados, tales como Simón Bolívar, y antiguos soldados profesionales, como José de San Martín, alcanzaron inmenso poder y prestigio al dirigir las sangrientas batallas libradas por la independencia. A pesar de que las instituciones -ayuntamientos, tribunales, parroquias, cabildos eclesiásticos- continuaron funcionando y aunque se formaron nuevos gobiernos y se eligieron congresos, predominó el poder militar.

En 1819 quedó muy claro que si el rey Fernando VII deseaba retener el control de América se vería obligado a enviar más tropas. Sin embargo, extraer los recursos necesarios para formar una nueva expedición que reconquistara el nuevo mundo sólo podría aumentar el descontento en el mismo y en la península. En España, los liberales sacaron ventaja del desencanto producido por la guerra en América y, finalmente, forzaron al rey a restablecer la Constitución de 1812 en marzo de 1820 . La restitución del orden constitucional transformó el sistema po- 
lítico hispánico por tercera vez en una década.

La restauración del gobierno constitucional provocó diversas respuestas en Hispanoamérica. Cuando en el mes de mayo llegaron las noticias al respecto, los habitantes de Nueva España y de Guatemala (América Central) se dedicaron con gran entusiasmo a restablecer el sistema constitucional. En los meses que siguieron se efectuaron elecciones para cubrir innumerables puestos en los ayuntamientos constitucionales, las diputaciones provinciales y las Cortes.

Sin embargo, la inestabilidad política existente en la península durante los últimos doce años había convencido a muchos novohispanos de que había que proceder con prudencia estableciendo un gobierno autónomo, pero dentro de la monarquía española. Los autonomistas y los miembros de la elite nacional, que finalmente ascendieron al poder después de la independencia, optaron por ello, por una monarquía constitucional. Se siguieron dos cursos de acción: buscar la autonomía dentro de la monarquía española y esforzarse por establecer un gobierno autónomo local.

Los diputados de Nueva España ante las Cortes propusieron un proyecto para establecer la autonomía en el nuevo mundo que consistía en crear tres reinos americanos gobernados por príncipes españoles aliados de la península. Con esta propuesta se hubiera formado una commonwealth (comunidad) española semejante a la posterior Commonwealth británica. De hecho, los diputados novohispanos razonaban que no deseaban seguir el ejem- plo de Estados Unidos. Por el contrario, como Canadá, planteaban retener lazos con la monarquía. La mayoría espanola en las Cortes, sin embargo, rechazó la propuesta que hubiera concedido además a los hispanoamericanos el autogobierno que habían buscado desde 1808.

Los autonomistas de Nueva España convencieron sobre la marcha al prominente coronel del ejército real, Agustín de Iturbide, de aceptar su plan de autonomía, plan que se asemejaba al presentado ante las Cortes. Mas, cuando Iturbide y sus partidarios obtuvieron el respaldo de la mayoría del ejército real, la independencia quedó asegurada. México logró así su emancipación no porque las autoridades reales fueran derrotadas militarmente, sino porque los novohispanos ya no apoyaban políticamente a la corona. ${ }^{47}$ Guatemala también declaró su independencia y se unió al nuevo imperio mexicano; Centroamérica, por su parte, se separó en forma pacífica en 1823, después de la abolición de este imperio, y formó una nación separada.

Los mexicanos recientemente emancipados siguieron paulatinamente los precedentes del sistema constitucional hispánico. Si bien en un principio establecieron un imperio, en 1824 formaron una república federal. Su nueva Constitución seguía las pautas de la carta española de 1812 , debido a que ésta era parte de su reciente experiencia política. Distinguidos hombres de Estado novohispanos, como José Gu322.

\footnotetext{
${ }^{47}$ Rodríguez, "Transición", 1993, pp. 265-
} 


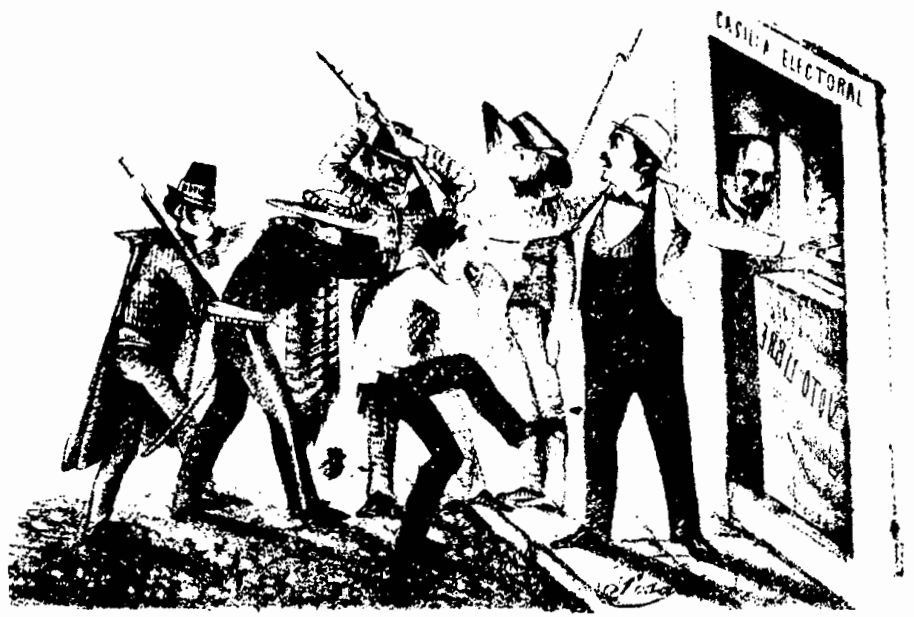

ridi y Alcocer y Miguel Ramos Arizpe, habían participado en la elaboración de dicha Constitución y, posteriormente, sirviernn en el Congreso constituyente mexicano. Para muchos mexicanos, la Constitución de 1812 era tan suya como de los españoles. Los diputados de la nueva nación se mantuvieron fieles a las prácticas constitucionales hispánicas y crearon un gobierno con una legislatura poderosa y una rama ejecutiva débil. De igual forma, el federalismo surgió en México de manera natural, referido a su anterior experiencia política. Las diputaciones provinciales, creadas por la Constitución hispánica para gobernar las provincias, se transformaron naturalmente en estados. ${ }^{48} \mathrm{Al}$ igual que México, la nueva

${ }^{48}$ Sobre este punto consúltese a Benson, Provincial, 1992. república centroamericana estableció una federación basada en prácticas constitucionales hispánicas.

En América del Sur, la restauración de la Constitución hispánica brindó a los independendistas la oportunidad de continuar su campaña para liberar al continente. Al contrario de lo acontecido en Nueva España y en Centroamérica, los insurgentes sudamericanos sí derrotaron militarmente al régimen español. Estos dos movimientos en forma de pinzas, uno proveniente del sur y el otro del norte, convergieron en un momento dado en el Perú.

Las dos tradiciones políticas en pugna emergieron durante el periodo de independencia: una, forjacla durante más de una década de guerra, hacía hincapié en la fuerza del poder ejecutivo; mientras que la otra, basada en la experiencia civil parlamentaria, insistía en el predominio del poder legislativo. 
Estas dos fuerzas representaban un conflicto fundamental en la naturaleza del gobierno. Nueva España, que alcanzó su independencia por medio del compromiso político y no por la fuerza de las armas, es representativa de la tradición civil. Allí, el sistema constitucional hispánico triunfó y continuó desarrollándose. A pesar de que hubo golpes militares subsecuentes, los políticos civiles dominaron la política mexicana.

El norte de la América del Sur, por el contrario, fue finalmente liberado por la fuerza militar. A diferencia de México, en Colombia, Perú y Bolivia los hombres de armas dominaron a los hombres de leyes. La experiencia constitucional hispana no influyó de manera apreciable en la región. Las tres naciones sudamericanas independizadas recientemente, establecieron gobiernos centralistas fuertes, con jefes del poder ejecutivo poderosos y con legislaturas débiles. En 1830, la Colombia, denominada en ocasiones como la Gran Colombia, se desgajó en tres países: Venezuela, Nueva Granada y Ecuador. No obstante, resultó difícil poner fin a la preponderancia de los militares.

El Cono Sur, que también había ganado su independencia con base en la fuerza, no cayó bajo el control de los militares. Allí el combate con las fuerzas reales había sido mínimo; la mayoría de los conflictos ocurrieron entre las provincias que luchaban por obtener su autonomía respecto a sus ciudades capitales. Con el paso del tiempo, Chile estableció una república oligárquica altamente centralizada, en tanto que en el Río de la Plata, los diversos gobiernos provinciales formaron una débil confederación. A pesar de la di- ferencia entre los dos países, los civiles dominaron ambas naciones. ${ }^{49}$

\section{LOS RESULTADOS DE LA INDEPENDENCIA}

En gran parte, el destino de las nuevas naciones de América fue resultado del momento oportuno. La lucha británico-americana por la independencia fue también parte de un conflicto internacional mayor. Pero la nueva nación logró su independencia y su reconocimiento diplomático, como parte de un acuerdo internacional, el Tratado de París de 1783. Como resultado, Estados Unidos no tuvo que invertir grandes cantidades de dinero en su defensa, ni tampoco tuvo, como los países hispanoamericanos, que dedicar más años de esfuerzo político y diplomático a obtener el reconocimiento de una agraviada madre patria. Fortuitamente, Estados Unidos disfrutó de una prosperidad de posindependencia a causa de los 20 años de guerra que se desataron en Europa. La revolución francesa de 1789 y las guerras que siguieron generaron una insaciable demanda de productos estadunidenses. Además, la participación española en esas guerras creó una gran oportunidad comercial para la joven república, porque la monarquía se vio obligada a depender de embarcaciones neutrales en su comercio con la América española. Las tensiones políticas y sociales dentro de Estados Unidos se mitigaron gracias a su prosperidad económica.

\footnotetext{
${ }^{49}$ Rodríguez, Independencia, 1996, pp. 99293.
} 
Además, la independencia de Estados Unidos, no produjo la destrucción política ni económica del mundo británico. A pesar de que hubo conflictos breves y relativamente menores, las relaciones culturales, económicas y diplomáticas prosiguieron entre la antigua metrópoli y la antigua colonia. Más importante, durante el siglo XIX, Gran Bretaña se convirtió en el poder industrial, comercial, financiero, tecnológico y naval más potente del mundo. La historia de Estados Unidos hubiera sido considerablemente diferente si España hubiera logrado esa preeminencia, en tanto que Gran Bretaña se hubiera derrumbado. En un mundo dominado por un país con una lengua, una religión y una cultura diferentes, Estados Unidos hubiera sido menos privilegiado políticamente, menos capaz de explotar sus ricos recursos fácilmente disponibles, además de que no hubiera estado libre de vecinos poderosos. Esto, claro, no aconteció. En lugar de ellos, Estados Unidos creció territorialmente por medio de la conquista, se expandió económicamente y mantuvo un sistema político estable que se ha hecho cada vez más democrático.

No obstante que Haití comenzó su proceso de independencia, como las otras partes de América, continuando patrones y procesos gestados durante años, experimentó luego una profunda revolución social y política. En un principio, Saint Domingue participó de las transformaciones de la revolución francesa, pero los esclavos, a quienes se excluyó de los cambios, insistieron en obtener libertad e igualdad. $\mathrm{Y}$ las sangrientas y destructivas guerras necesarias para lograr sus metas amenazaron el futuro económico y político de la isla. Mas, como observa Knight,

los haitianos transformaron completamente su agricultura, pasando de las plantaciones tropicales convencionales basadas en una estructura dominada por el latifundio, a una sociedad minifundista, o sea de productores independientes, autosuficientes en pequeña escala, que reorientaron su producción alejándola de la dependencia de la exportación y enfocándola hacia un sistema de mercado interno complementado por un mercado de exportación minoritario. ${ }^{50}$

Además, como era una revolución realizada por antiguos esclavos, gente de ascendencia africana, causó terror en la sociedad blanca de América y Europa, y como los ejércitos europeos no lograron subyugarlos, fueron aislados; y cuando algunos de ellos procuraron continuar con las exportaciones de azúcar, les cerraron el mercado completamente. En su lugar, las naciones europeas establecieron la provechosa agricultura tropical en otras islas caribeñas. Así, los ciudadanos de Haití fueron imposibilitados para formar una nación económicamente próspera y políticamente estable, en una tierra empobrecida y aislada.

La emancipación de la América española consistió en su separación de la madre patria, al igual que en el caso de Estados Unidos. Pero a diferencia del caso de la América británica, el proceso de independencia de la América española destruyó un enorme y muy sensi-

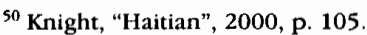


ble sistema social, político y económico que funcionaba relativamente bien, pese a sus muchas imperfecciones. La monarquía española universal había demostrado, durante casi 300 años, que era flexible, así como capaz de reacomodar las tensiones sociales y los intereses económicos y políticos conflictivos. Pese a sus deficiencias y desigualdades, la monarquía funcionó efectivamente como sistema económico y, por su calidad unitaria, tuvo la fuerza necesaria para participar de manera efectiva en la economía mundial. En la época posterior a la independencia se hizo evidente que, individualmente, las partes separadas de la antigua monarquía española se encontraban en desventaja ante la competencia. Desde este punto de vista, la España del siglo XIX, al igual que los reinos americanos, era ya sólo una más de las nuevas naciones independientes, que buscaba a tientas un lugar estable en un mundo incierto e inhóspito.

Así, para 1826 las posesiones ultramarinas de la monarquía española, una de las estructuras políticas más imponentes del mundo de finales del siglo XVIII, eran sólo Cuba, Puerto Rico, Filipinas, y unas cuantas islas en el Pacífico. A diferencia de Estados Unidos, que había obtenido su independencia en 1783 -tiempo para beneficiarse de la insaciable demanda de productos generada durante los 20 años de guerras europeas que siguieron a la revolución francesa de 1789- el mundo español alcanzó su emancipación después de que terminaron las guerras en Europa. Entonces las nuevas naciones no sólo tuvieron que reconstruir sus destrozadas economías, sino tam- bién enfrentar la falta de demanda para sus productos. En lugar de comprar, Europa y Estados Unidos se hallaban ansiosos de inundar la América espanola con sus propios artículos. Por tanto, los nuevos países no gozaron de prosperidad durante sus años de formación, como sí le había ocurrido a Estados Unidos. En vez de ello, los Estados hispanoamericanos tuvieron que enfrentar graves problemas internos y externos con recursos muy limitados.

La experiencia decimonónica de España y América muestra claramente el costo de la independencia. Las dos regiones vivieron el caos político, la declinación económica, el imperialismo económico y la intervención extranjera. Tanto la península como las naciones del nuevo mundo soportaron guerras civiles y pronunciamientos militares. En sus esfuerzos por resolver sus crisis políticas y económicas, España y América recurrieron a establecer la monarquía y la república, el centralismo y el federalismo, el gobierno representativo y la dictadura. Desafortunadamente, no existía una solución fácil para aquellas naciones cuya economía había sido destruida por la guerra y cuyo sistema político había sido destrozado por la revolución.

Fue sólo en el último tercio del siglo XIX que las naciones de América, al igual que España, comenzaron a lograr la consolidación de sus Estados. En los decenios de 1870 y 1880 , tanto España como la mayoría de los países de Hispanoamérica impusieron gobiernos estables y emprendieron el difícil proceso de rehabilitarse económicamente. Desafortunadamente, los miembros de la antigua monarquía española 


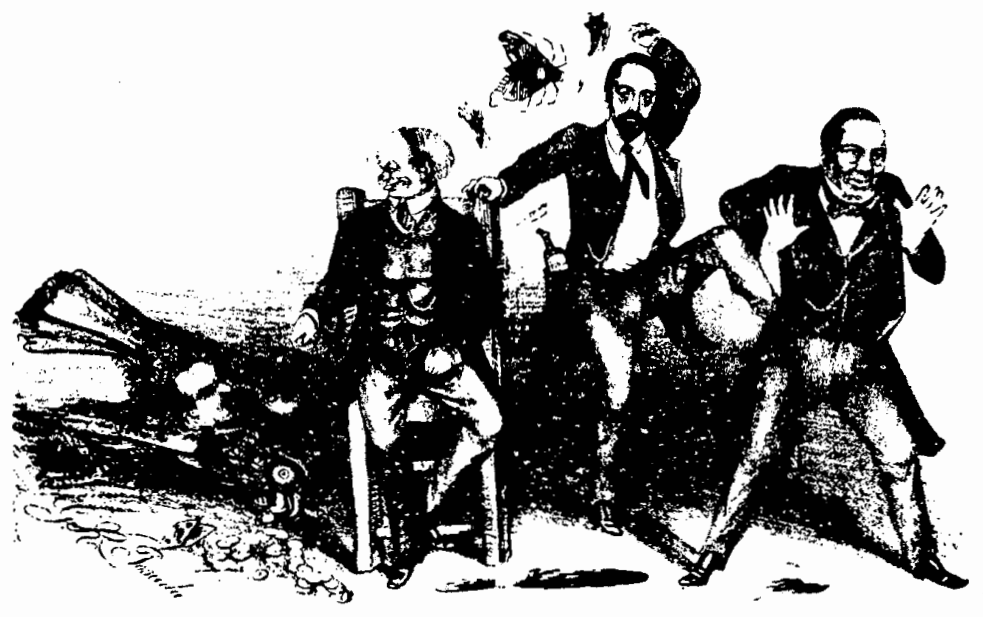

habían languidecido durante 50 años decisivos, en los cuales Gran Bretaña, Francia, Alemania y Estados Unidos habían avanzado hacia una etapa diferente de desarrollo económico. Luego, durante el periodo siguiente a la gran revolución política que disolvió la monarquía española, el mundo del norte del Atlántico cambió espectacularmente. Las corporaciones industriales y las instituciones financieras de Europa occidental y de Estados Unidos habían alcanzado tal fuerza y tamaño que las economías emergentes de Hispanoamérica y de España no pudieron competir con ellas. Como resultado de ello, los antiguos miembros de la monarquía española fueron obligados a aceptar un papel secundario en el nuevo orden mundial.

\section{Biblografía}

-Belenguer, Ernest, El imperio bispánico, 1479-1665, Grijalbo Mondari, Barcelona, 1994.

-Benson, Nettie Lee, The Provincial Deputation in Mexico: harbinger of provincial autonomy, independence, and federalism, University of Texas Press, Austin, 1992.

-Brown, Roger H., Redeeming the Republic: federalists, taxation, and the origins of the Constitution, The Johns Hopkins University Press, Baltimore, 1993.

-Bruchey, Stuart, The roots of american economic growth, 1607-1861, Harper \& Row, Nueva York, 1965.

-Burkholder, Mark A. y Lyman L. Johnson, Colonial Latin America, Oxford University Press, 2a. ed., Nueva York, 1994.

-Canny, Nicolas P., "The ideology of english colonization: from Ireland to America", William and Mary Quarterly, 34d., ser. XXX, 1973, pp. 575-598. 
-Draper, Theodore, A struggle for power: the american revolution, Random House, Nueva York, 1996.

-Eccles, W. J., France in America, Fitzhenry \& Whiteside, Markham, Ontario, 1990 , ed. revisada.

-Elliott, John H., "A Europe of composite monarchies", Past and Present, núm. 137, 1992, pp. 52-69.

-Fick, Carolyn E., The making of Haiti: the Saint Domingue revolution from below, University of Tennessee Press, Knoxville, 1990.

-Gibson, Charles, The aztecs under spanish rule: a bistory of the indians of the valley of Mexico, 1519-1810, Stanford University Press, Stanford, 1964.

-González, María del Refugio, Historia del derecbo mexicano, McGraw-Hill/UNAM, 2a. ed., México, 1997.

-Grafenstein Gareis, Johanna von, Nueva España en el Circuncaribe, 1779-1808: revolución, competencia imperial y vinculos intercoloniales, UNAM, México, 1997.

-Greene, Jack P., "The american revolution", The American Historical Review, vol. 105, núm. 1, febrero 2000, pp. 93-102. , Understanding the american revolution, University Press of Virginia, Charlottesville, 1995.

-Greengrass, Mark (comp.), Conquest and coalescence: the shaping of the State in early modern Europe, Routledge, Chapman and Hall, Nueva York, 1991.

-Guedea, Virginia, "Las primeras elecciones populares en la ciudad de México, 1812-1813", Mexican Studies/Estudios Mexicanos, vol. 7, núm. 1, invierno 1991, pp. 1-28.

$\longrightarrow$, "El pueblo de México y la política capitalina, 1808-1812", Mexican Studies/Estudios Mexicanos, vol 10, núm. 1, invierno 1994, pp. 27-61.

,"The process of mexican independence", The American Historical Review, vol. 105, núm. 1, febrero 2000, pp. 116-130. terno: los Guadalupes de México, UNAM, México, 1992.

-Haskett, Robert, Indigenous rulers: an etbnobistory of town government in colonial Cuernavaca, University of New Mexico Press, Albuquerque, 1991.

-Hernández Guerrero, Dolores, La revolución baitiana y el fin de un sueño colonial (1791-1803), UNAM, México, 1997.

-Higgenbotham, Don, The war for american independence, military attitudes, policies, and practice, 1763-1789, Harper, Nueva York, 1971.

-Horsman, Reginal, Race and manifest destiny: the origins of american racial anglo-saxonism, Harvard University Press, Cambridge, 1981.

James, C. L. R., The black jacobins: Toussaint Louverture and the San Domingo revolution, Ellison \& Busby, 3a. ed., Londres, 1980.

-Jensen, Merrill, The Articles of Confederation, University of Wisconsin Press, 2a. ed., Madison, 1959.

-Knight, Franklin W., "The haitian revolution", The American Historical Review, vol. 105, núm. 1, febrero de 2000, pp. 103-115.

-Lira, Andrés, Comunidades indigenas frente a la ciudad de México: Tenocbtitlan y Tlatelolco, El Colegio de Michoacán, Zamora, 1983.

-MacLachlan, Colin M. y Jaime F. Rodriguez O., The forging of the Cosmic Race: a reinterpretation of colonial Mexico, University of California Press, 2a. ed., Berkeley, 1990.

-Maier, Pauline, From resistance to revolution: colonial radicals and the development of american opposition to Britain, 1765-1776, W. W. Norton, Nueva York, 1991.

-Merriman, Roger B., The rise of the Spanish Empire in the old world and the new, The Macmillan Co., Nueva York, 1918-1934, 4 vols. 
-Meyer, Jean, Francia y América del siglo XvI al siglo XX, Mapfre, Madrid, 1992.

-Middlekauff, Robert, The glorious cause: the american revolution, 1763-1789, Oxford University Press, Nueva York, 1982.

-Mier, Servando Teresa de, "Idea de la Constitución dada a las Américas por los reyes de España antes de la invasión del antiguo despotismo" en Jaime E. Rodríguez $\mathrm{O}$. (comp.), Obras completas de Servando Teresa de Mier, vol. 4, La formación de un republicano, UNAM, México, 1988, pp. 33-80.

-Miranda, José, Las ideas y las instituciones politicas mexicanas, UNAM, México, 1978.

-Morgan, Edmund S., American slavery and american freedom: the ordeal of colonial Virginia, W. W. Norton, Nueva York, 1975.

-Ott, Thomas O., The baitian revolu. tion, 1789-1804, University of Tennessee Press, Knoxville, 1973.

-Phelan, John L., The people and the king: the comunero revolution in Colombia, 1781, University of Wisconsin Press, Madison, 1978.

-Rodriguez O., Jaime E., "La transición de colonia a nación: Nueva España, 18201821", Historia Mexicana, vol. xlIII, núm.
2 , octubre-diciembre de 1993 , pp. 265 . 322.

$\longrightarrow, L a$ independencia de la América española, Fondo de Cultura Económica, México, 1996.

- "Las primeras elecciones constitucionales en el Reino de Quito, 1809-1814 y 1821-1822", ponencia presentada en el Congreso Internacional El 'Tiempo de las Independencias en la América Española, efectuado en Morelia, Michoacán, México, julio 21-23, de 1999.

-Seed, Patricia, "'Are these not also men?': the indians' humanity and capacity for spanish civilization", Journal of Latin American Studies, vol. 25, núm. 3, octubre de 1993, p. 651. , Ceremonies of possession in Europe's conquest of the new world, 1492-1640, Cambridge University Press, Cambridge, 1995.

-Smelser, Marshal, The winning of independence, Quadrangle, Chicago, 1972.

-Wallace, Willard M., Appeal to arms: a military bistory of the american revolution, Harper, Nueva York, 1951.

-Wood, Gordon S., The radicalism of the american revolution, Alfred A. Knopf, Nueva York, 1992. 